\title{
The Relationships Among Teachers' Behaviours That Encourage Students' Reading Engagement, Reading Enjoyment, Reading Self-Efficacy and Reading Success
}

\author{
Pakize URFALI DADANDI* \\ Department of Turkish and Social Sciences Education, \\ Yozgat Bozok University, Yozgat, Turkey \\ ORCID: 0000-0002-8364-9408
}

İbrahim DADANDI

Department of Educational Sciences, Yozgat Bozok University, Yozgat, Turkey ORCID:0000-0003-1503-0272

\section{Article history}

Received:

26.03.2021

Received in revised form: 12.10.2021

Accepted:

11.11.2021

Key words:

Reading engagement, Reading enjoyment, Reading self-efficacy, Reading success.
Reading comprehension has a critical importance for almost every aspect of individuals' life. The aim of this study is to reveal the relations among students' perceptions of their Turkish language teachers' behaviours that encourage reading engagement, levels of reading enjoyment, reading selfefficacy, and reading success within the frame of a model, using PISA 2018 Turkey data. The study is based on the correlational research model and the sample includes $6450(\mathrm{~F}=3247, \mathrm{M}=3203)$ students who completed the PISA 2018 Turkey questionnaire. The data obtained from the PISA 2018 database were analyzed using the structural equation model (SEM) and the sobel test. SEM analyses revealed that the hypothesized model well fits the data and all the regression paths in the model are statistically significant. According to the research findings, teachers' behaviours that encourage students' reading engagement (TBESRE), reading enjoyment, and reading self-efficacy have significant direct effects on reading achievement. In addition, TBESRE has significant indirect effects on reading achievement through reading enjoyment and reading self-efficacy, and that reading self-efficacy has a significant indirect effect on reading achievement through reading enjoyment. Considering the findings of this study, it is recommended that teachers implement practices to encourage students' participation in reading activities and develop educational interventions to improve reading enjoyment and reading self-efficacy.

\section{Introduction}

In today's modern societies, people perform countless reading activities in daily life, consciously or unconsciously. The modern lifestyle in the information age makes reading indispensable in daily life and one of the basic skills needed at every stage of life, from

\footnotetext{
*Correspondency: pakizeurfali@gmail.com
} 
childhood to death. Being a good reader has a critical role in an individual's educational success, as well as in terms of joining the workforce after education and achieving personal autonomy. For this reason, determining the factors affecting students' reading success, which will ultimately guide the efforts aiming to improve reading, is among the central issues of reading research. Whilst classical theories emphasize cognitive processes such as vocabulary, prior knowledge, and reading fluency in explaining reading (Samuels \& Kamil, 1998), contemporary models are increasingly interested in psychological constructs such as personality traits and motivational constructs (e.g., Kuşdemir \& Bulut, 2018; Pecjak, Podlesek \& Pirc, 2011; Toste et al., 2020). In this context, one of the most emphasized psychological structures is level of students' engagement, which is accepted as one of the indicators of their motivation.

The term student engagement is generally used to express the level of cognitive, emotional, and behavioural connection and commitment of students to school and educational activities (Fredricks, Blumenfeld \& Paris, 2004; Newman, Wehlage \& Lamborn, 1992). Although the definition of student engagement differs among researchers, many definitions emphasize educationally desirable attitudes and behaviours such as being willing to learn and put effort in lessons, setting personal goals, developing positive attitudes towards teachers, classmates and school, feeling belonging to the school, being active in school lessons and extracurricular activities, obeying school and classroom rules, and demonstrating positive attitudes (Baron \& Corbin, 2012; Finn \& Zimmer, 2012; Fredricks et al., 2004; Linnenbrink \& Pintrich, 2003). In parallel with this general conceptualization, reading engagement is defined as an individual's cognitive, emotional, and behavioural involvement and dedication to the reading process (Guthrie, McRae \& Klauda, 2007). The literature highlights a positive relationship between reading engagement and reading success (Guthrie \& Wigfield, 2005; Taboada, Townsend \& Boynton, 2013). Students with high reading engagement set reading goals, value reading, believe they are good readers, and are more willing to reading activities (Barber \& Klauda, 2020). Therefore, one way to increase reading success may be to improve the factors that affect students' engagement. Although various individual and socio-demographic characteristics of students can affect their level of engagement, the main factor that strengthens engagement is to what extent teachers are perceived as supportive, collaborative, and open to communication by their students in the teaching-learning process (Klem \& Connell, 2004; Parsons \& Taylor, 2011). Teachers' positive behaviours such as providing enriched teaching materials and well-planned lessons, asking thought-provoking questions, adopting a democratic classroom management, creating a collaborative learning environment, considering students' distinctions, and being sensitive to their needs strengthen students' engagement to education and the relevant course by making the learning environment more attractive (Inda-Caro, Maulana, Fernández-García, Peña-Calvo, del Carmen RodríguezMenéndez \& Helms-Lorenz, 2019; Sherab, 2013; Zepke \& Leach, 2010). Therefore, it is obvious that teachers' behaviours that encourage engagement during reading activities are quite important for students' reading success. On the other hand, in the literature on teacherstudent relations, it is also emphasized that positive and supportive teacher attitudes contribute not only to students' academic success but also to affective characteristics associated with their achievement (Sabol \& Pianta, 2012). Therefore, it is concluded that teachers' behaviours that encourage reading engagement will also have a positive effect on students' levels of reading enjoyment and reading self-efficacy.

Reading is a complex process that includes both cognitive and emotional components. Thus, it is inevitable that, along with cognitive variables such as vocabulary and reading fluency, readers' attitudes and feelings towards reading affect their reading success. The concept of 
reading enjoyment, which means positive feelings about reading and reading material, is one of the important components of attitudes towards reading (Aarnoutse, \& van Leeuwe, 1998). Students who enjoy reading spend more time on reading. Without an academic purpose or the instruction of a teacher or an adult, they read just because they enjoy reading. Although this type of reading is mostly done outside of the classroom and has no academic purpose (Jennifer \& Ponniah, 2015), it serves many of the benefits of the mere act of reading. Reading for enjoyment improves students' writing and reading comprehension skills, increases their general knowledge, enriches their vocabulary, and strengthens their self-confidence in reading (Clark \& De Zoysa, 2012). Therefore, reading enjoyment helps students develop reading habits and be more successful by facilitating their reading for academic purposes (Cunningham \& Stanovich, 1998; Jennifer \& Ponniah, 2015). However, students who do not like to read cannot benefit from the benefits of reading activities and are deprived of many learning opportunities. As a natural consequence of reading less, their reading skills do not improve either. Thus, they remain poor readers (Juel \& Leavell, 1988).

Another psychological factor associated with students' reading success is self-efficacy beliefs. Self-efficacy is defined as an individual's belief in his or her own capacity to organize and carry out the necessary action steps to reach a certain level of performance or success. (Bandura, 1995). In other words, it refers to judgments about what an individual can do and to what extent he/she can meet predetermined success criteria with his/her personal abilities and skills (Maddux, 2002). According to the Social Cognitive Theory, which constitutes the theoretical basis of the self-efficacy concept, people direct their own behaviours through personal agency mechanisms they have. Self-efficacy, as the most important of the personal agency mechanisms, has a critical importance on the success and motivation of students (Bandura, 1982). Students with strong self-efficacy beliefs put more effort in accomplishing academic tasks, persevere in the face of difficulties and failure, set higher goals for themselves, and ultimately achieve higher levels of success (Pajares, 2006). Theoretically, self-efficacy has a multidimensional nature, consisting of domain-specific efficacy beliefs rather than a general personality trait. Therefore, reading success is associated with reading self-efficacy rather than general self-efficacy. Schunk and Zimmerman (1997) define reading self-efficacy as individual's belief in his/her own capacity to read effectively and successfully. Guthrie and Wigfield (2000) emphasize the importance of motivational processes in reading success. Reading self-efficacy is among the basic components of reading motivation that directs students to read more and contributes significantly to reading success (Wigfield \& Guthrie, 1997). The literature reveals that reading self-efficacy affects reading achievement both directly (Guthrie, Klauda, \& Ho, 2013; Schöber, Schütte, Köller, McElvany \& Gebauer, 2018) and indirectly through secondary processes affecting reading achievement such as using reading and self-regulation strategies (Klassen, 2010; Schunk \& Rice, 1993).

Current reading research emphasizes positive relationships between supportive teacher behaviors and students' reading skills (Okkinga, van Steensel, van Gelderen, \& Sleegers, 2018; Zhao, Song, Zhao, \& Zhang, 2019). However, most of these studies examined the relationship between the two variables through linear models and ignoring the psychological factors that affect students' reading success. As a result, little is known about the mechanisms underlying the relationship between positive teacher behaviours and higher reading achievement. Considering that reading is a complex skill affected by many cognitive, environmental, and psychological factors, it can be argued that there is a need for models to explain how these variables interact in explaining reading success. This study aims to test a model to explain the relationships between Turkish teachers' behaviors encouraging reading engagement, reading pleasure, reading self-efficacy, and reading success, using PISA 2018 
Turkey data. This model is presented in Figure 1 and consists of the following hypotheses.

(1) Teachers' behaviors encouraging reading engagement significantly predict reading self-efficacy.

(2) Teachers' behaviors encouraging reading engagement significantly predict reading enjoyment.

(3) Teachers' behaviors encouraging reading engagement significantly predict reading success.

(4) Reading enjoyment significantly predicts reading success.

(5) Reading self-efficacy significantly predicts reading success.

(6) Reading self-efficacy significantly predicts reading enjoyment.

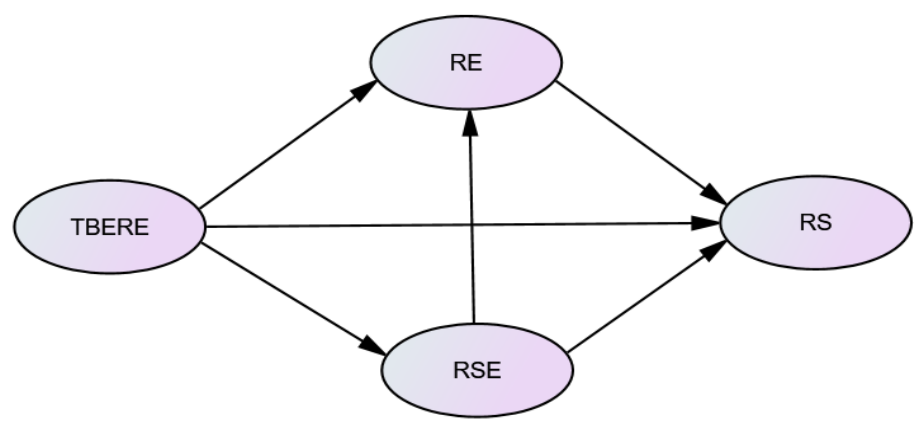

Figure 1. Hypothesized model

Note: TBERE $=$ Teachers' behaviours encouraging reading engagement; $R E=$ Reading Enjoyment; RSE= Reading self-efficacy; RS= Reading success

\section{Method}

The research was designed based on the correlational research design. Correlational studies investigate whether there are significant relationships between two or more variables and the strength of these relationships (Ary, Jacobs, \& Sorensen, 2010). In this respect, the main purpose of correlational research is to clarify the events and facts by defining the relationships between the variables. Correlational studies also allow for prediction of the causal effect of independent variables on the dependent variable (Fraenkel, \& Wallen, 2009).

\section{Research Group}

The sample of this study consists of 15-year-old students participating in the PISA 2018 Turkey practice. The schools to be included in the Turkey sample of the PISA 2018 practice were determined by the stratified random sampling method. A total of 6890 students from 186 schools completed the questionnaires. Of the students, $78.8 \%$ are in the 10th grade, $17.7 \%$ are in the 9 th grade and $2.9 \%$ are in the 11th grade. However, 440 observations with missing data were excluded from the data set of this study. Therefore, the analyses were performed with the data obtained from $6450(\mathrm{~F}=3247, \mathrm{M}=3203)$ students.

\section{Data Source}

The data of the study were obtained from the PISA database. The Organization for Economic Cooperation and Development provides open access for researchers to all data obtained from student, teacher, and family surveys of the PISA practice. The PISA database 
contains data collected from all participating countries. In this study, Turkey data from the PISA student questionnaire was used.

\section{Variables}

\section{Reading Success}

In PISA practices, "Plausible values" are used to describe students' performance instead of test scores. Plausible values refer to a set of special performance indicators, using the multiple imputations, based on students' answers to test questions (Mislevy, 1991). In PISA assessments, 10 plausible values are calculated per student for each test. In this study, the plausible values for reading literacy (PV1READ - PV10READ), calculated as an indicator of students' performance in reading, were used to evaluate reading success.

\section{Teachers'Behaviours Encouraging Reading Engagement}

Teachers' behaviours encouraging reading engagement was assessed with the teachers' stimulation of reading engagement scale of PISA student questionnaire. The items of this scale are under the ST152 code in the PISA student questionnaire and are used to evaluate students 'perceptions of their teachers' level of encouragement to participate in reading activities in Turkish lessons. This scale consists of four items in a four-degree Likert type ("The teacher encourages students to share their views on the text."; "The teacher helps students make connections between their lives and the stories they read."; "The teacher shows students how to relate the information in texts to their previous knowledge." and "The teacher asks students questions that motivate them to participate more actively into lessons."). These items, which are coded as ST152Q05IA, ST152Q06IA, ST152Q07IA and ST152Q08IA in the PISA 2018 database, are recoded as TB1, TB2, TB3 and TB4, respectively for clarity.

\section{Reading Enjoyment}

Items under the ST160 code in the PISA student questionnaire were used to assess reading enjoyment. In the PISA student questionnaire, there are five items designed in a fourpoint Likert type to measure students' reading enjoyment ("I only read something when I have to"; Reading is one of the activities I enjoy in my leisure time; "I like talking to others about books."; "To me, reading is wasting time./Reading is a wasted time for me",;" I just read to get the information I need. "). Items 1, 4, and 5, which have negative meanings, are reversely scored during the analysis process. The questionnaire items coded as ST160Q01IA, ST160Q02IA, ST160Q03IA, ST160Q04IA, ST160Q05IA in the PISA 2018 database arecoded as RE1, RE2, RE3, RE4 and RE5, respectively in the study.

\section{Reading Self-Efficacy}

Reading self-efficacy was evaluated with the items under the ST161 code in the PISA 2018 student questionnaire. This scale includes six items designed in a four-point Likert type and aims to measure students' reading self-concepts in two dimensions: Perception of competence and perception of difficulty. The competence dimension, which includes the first three items, aims to measure students' perceptions of self-efficacy regarding reading. Therefore, these three items ("I am a good reader."; "I can understand difficult texts"; "I read fluently.") were used as indicators of reading self-efficacy in this study. These items, which are coded as ST161Q01HA, ST161Q02HA, ST161Q03HA in the PISA 2018 database, are recoded as SE1, SE2 and SE3, respectively for clarity. 


\section{Data Analysis}

In the data analysis process, first of all, missing data in the data set examined. Missing data for each item in the indicator variables were determined and excluded from the analysis. Thus, observations obtained from 440 students, who did not answer one or more questions in student questionnaire items, were removed from the data set.

Relationships between variables and the hypothesis model of the study were analysed with the Structural Equation Model (SEM) by using the AMOS 22.0 statistics package program. To evaluate model fit, $\mathrm{X}^{2} / \mathrm{d} f$, Comparative Fit Index (CFI), Goodness of Fit Index (GFI), Adjusted Goodness of Fit Index (AGFI), Standardized Root Mean Square Residual (SRMR) and Root Mean Square Error of Approximation (RMSEA) were used. Cut-off values for these fit indices were accepted as $\chi^{2} / \mathrm{d} f \leq 5$, CFI $\geq .90$, GFI $\geq .90$, AGFI $\geq .90$, RMSEA $\leq .60$ and SRMR $\leq .10$ (Bentler, 1990; Byrne, 2010). To evaluate whether indirect effects are significant or not, the Sobel test was used.

\section{Results}

\section{Measurement Model Results}

In SEM analysis, the measurement model should be tested before testing the structural model (Schreiber, Nora, Stage, Barlow, \& King, 2006). In the measurement model analysis, the relationships among latent variables and factor loadings of indicator variables are examined (Byrne, 2010). Initial analysis revealed that the fit indices of the measurement model were insufficient $\left(\chi^{2} / \mathrm{d} f=6.92\right.$, GFI $=.97$, AGFI $=.96$, CFI $=.89$, RMSEA $=.03$, SRMR $=.05)$. To improve model fit, the modifications suggested by AMOS were examined and covariances were added between the errors of some indicator variables. After these modifications, fit indices of the measurement model were found to be acceptable $\left(\chi^{2} / \mathrm{d} f=\right.$ 5.36 , GFI $=.98$, AGFI $=.97, \mathrm{CFI}=.93$, RMSEA $=.03, \mathrm{SRMR}=.05)$. The factor loadings of the observed variables are presented in Table 1, and the relationships among latent variables in the model are presented in Table 2.

Table 1. Factor loadings for latent variables

\begin{tabular}{lll}
\hline Latent Variable & Observed Variable & Factor loading \\
\hline \multirow{3}{*}{ TBERE } & TB1 & .810 \\
& TB2 & .742 \\
& TB3 & .875 \\
& TB4 & .740 \\
\hline \multirow{2}{*}{ RE } & RE1 & .643 \\
& RE2 & .817 \\
& RE3 & .782 \\
\hline \multirow{2}{*}{ RSE } & RE4 & .632 \\
& RE5 & .572 \\
\hline & RSE1 & .917 \\
& RSE2 & .622 \\
& RSE3 & .671 \\
\hline \multirow{2}{*}{ RS } & PV1R & .956 \\
& PV2R & .956 \\
& PV3R & .953 \\
& PV4R & .954 \\
& PV5R & .956 \\
& PV6R & .956 \\
& PV7R & .955 \\
& PV8R & .955 \\
& PV9R & .956 \\
\hline
\end{tabular}


Table 2. Relationships among latent variables

\begin{tabular}{|c|c|c|c|c|}
\hline Table 2 & rat & 2 & 3 & 4 \\
\hline TRERF & 1 & & & \\
\hline $1.1 \mathrm{BE}$ & $25 * * *$ & 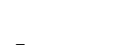 & & \\
\hline $\begin{array}{l}\text { 2. KE } \\
\text { 2. } \mathrm{PCE}\end{array}$ & $.25 * * *$ & $68 * * *$ & 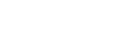 & \\
\hline 3. RSE & $.23 * * *$ & $.68 \% * *$ & $23 * * *$ & 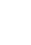 \\
\hline
\end{tabular}

$\mathrm{p}<.001$

As seen in Table 2, there are significant relationships among students' perceptions of their teachers' behaviours that encourage reading engagement, their level of reading enjoyment $(\mathrm{r}=$ $.25, \mathrm{p}<.001)$, reading self-efficacy $(\mathrm{r}=.23, \mathrm{p}<.001)$, and reading success $(\mathrm{r}=.25, \mathrm{p}<.001)=$ $.12, \mathrm{p}<.001)$. Similarly, there are significant relationships between reading success and reading self-efficacy $(\mathrm{r}=.23, \mathrm{p}<.001)$ and reading enjoyment $(\mathrm{r}=.28, \mathrm{p}<.001)$. Finally, reading enjoyment is significantly correlated with reading self-efficacy $(r=.23, p<.001)$.

\section{Structural Model Results}

After the measurement model analysis, the structural model was tested. Structural model analysis revealed that all paths defined in the model were significant. Fit indices of the model were found as $\chi^{2} / \mathrm{d} f=6.92, \mathrm{GFI}=.97$, AGFI $=.96, \mathrm{CFI}=.89$, RMSEA $=.03$, SRMR $=.05$. To improve model fit, covariances were added between the error terms of some observed variables in line with the modification indices (see Figure 1). After these modifications, SEM analysis revealed that the model had adequate fit to the data $\left(\chi^{2} / \mathrm{d} f=\right.$ $5.36, \mathrm{GFI}=.98, \mathrm{AGFI}=.97, \mathrm{CFI}=.93, \mathrm{RMSEA}=.03, \mathrm{SRMR}=.05)$. The final model results are shown in Figure 2.

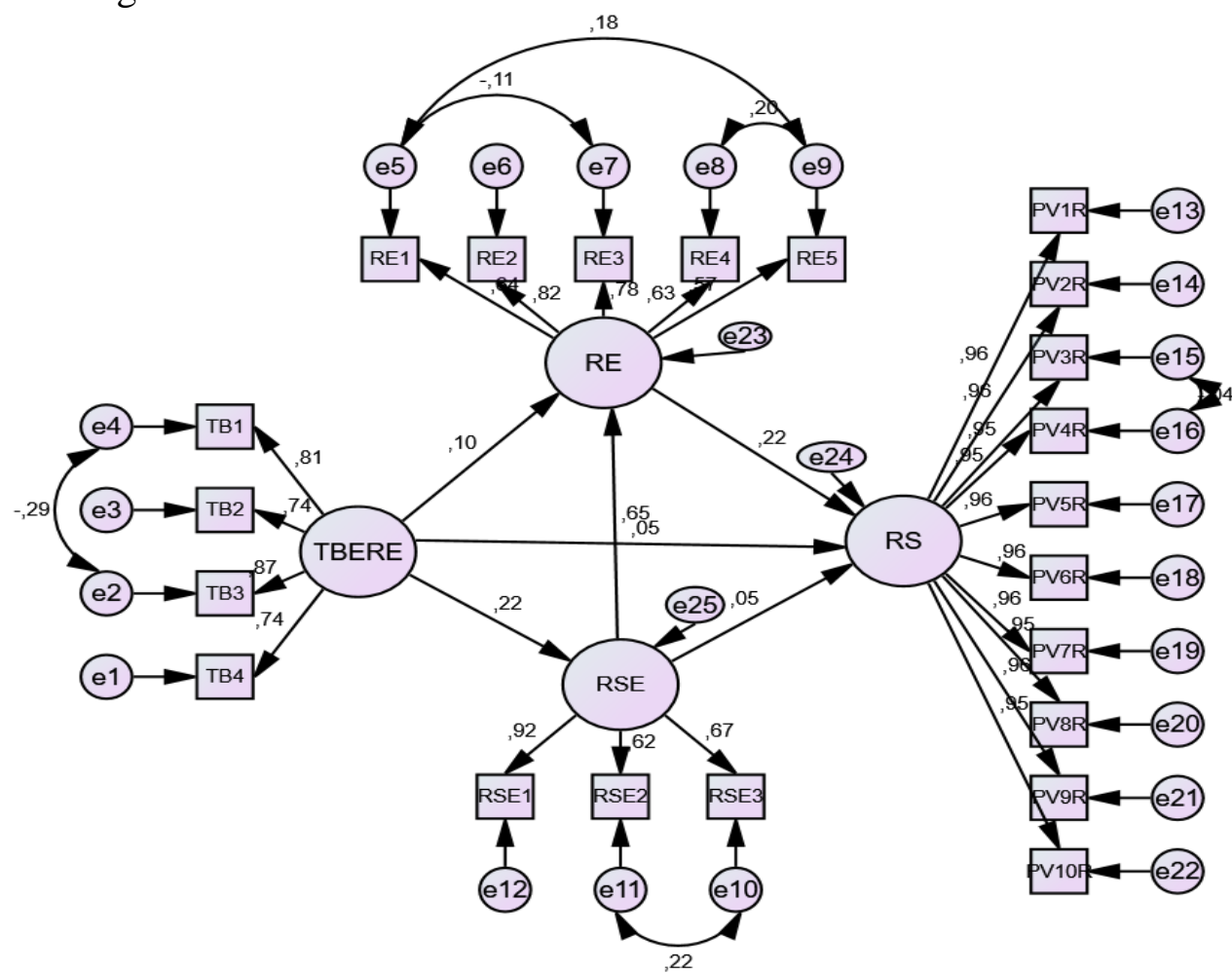

Figure 2. Final model 
The relationships among the research variables and the standardized regression coefficients are shown in figure 2. According to the analysis results, teachers' behaviours encouraging reading engagement significantly predict reading enjoyment $(\beta=.10, p<.001)$, reading selfefficacy $(\beta=.22, p<.001)$ and reading success $(\beta=.05, p<.001)$. In addition, reading selfefficacy significantly predicts the level of reading enjoyment $(\beta=.65, \mathrm{p}<.001)$ and reading success $(\beta=.05, p<.001)$. Finally, the level of reading enjoyment significant predicts reading success $(\beta=.22, \mathrm{p}<.001)$.

SEM analysis also revealed that teacher behaviors that encourage reading engagement indirectly affect reading success through self-efficacy and reading enjoyment. Also, reading self-efficacy has an indirect effect on reading achievement via reading enjoyment. The statistical significance of these indirect effects was examined with the Sobel test. The analyses reveal that indirect effects of teachers' behaviours that encourage reading engagement on reading success, through reading self-efficacy $(\mathrm{z}=2.42, \mathrm{p}<.01)$ and reading enjoyment $(\mathrm{z}=$ $6.38, \mathrm{p}<.001)$ were significant. Similarly, the indirect effect of reading self-efficacy on reading success via reading enjoyment was found to be significant $(\mathrm{z}=9.60, \mathrm{p}<.001)$. Therefore, it can be claimed that students' reading enjoyment levels and reading selfefficacies play partial mediating roles in the relationship between their perceptions of teachers' behaviours encouraging reading engagement and reading success. Likewise, reading enjoyment level plays partial mediating role in the relationship between reading self-efficacy and reading success.

\section{Discussion and Conclusion}

In this study, a model examining the relationship among students' perceptions of their teachers' behaviours that encourage reading engagement, reading enjoyment, reading selfefficacy and reading achievement is tested with PISA 2018 Turkey data. The results showed that the hypothesized model well fits the data and all the paths defined in the model are significant.

The findings of the study show that, among the variables in the model, the strongest predictor for reading success is the level of students' reading enjoyment. This finding is contrary to some previous studies (McGeown, Johnston, Walker, Howatson, Stockburn \& Dufton, 2015; Zaccoletti, Altoè \& Mason, 2017) which have suggested that there is no relationship between reading enjoyment and reading success. This inconsistency may be due to the difference in demographic characteristics of the samples. These studies were conducted with primary school students and interests may change with age. Since interests are structured through interaction with the environment, they are quite open to change in the early childhood years and become increasingly stable from adolescence due to increasing experiences (Slot, Akkerman, \& Wubbels, 2019). Therefore, while interpreting these findings, one should consider that primary school children may not have enough maturity and life experiences to evaluate whether they like to read or not in a realistic way. As a matter of fact, studies conducted on older age groups show that reading enjoyment is one of the predictors of reading success, confirming the findings of this study (Cheema, 2018; Ertem, 2020; Rogiers, Van Keer \& Merchie, 2020; Tavşancıl, Yıldırım, \& Demir, 2019). Students who have positive attitudes and feelings towards reading spend more time on reading in their daily lives (Özbay, Bağcı \& Uyar, 2008; Wilkinson et al., 2020). As stated earlier, reading has many benefits that ultimately improve reading, even if it has no specific academic purpose. The relevant literature emphasizes the positive relationship between total reading time and reading success (Locher \& Pfost, 2020; Stutz, Schaffner \& Schiefele, 2016). Taken together, it can be stated 
that students who enjoy reading devote more time to reading activities and thus they are more successful in reading since they have more opportunities to improve their reading skills.

The current study found that reading self-efficacy significantly predict reading achievement. This finding corroborates previous studies implying that there is a positive relationship between students' self-efficacy beliefs about reading and their reading achievement (Chen, Sakyi, \& Cui, 2020; Hornstra, van der Veen \& Peetsma, 2016; Sofyan \& Jayanti, 2019). For example, in a longitudinal study Peura et al. (2019) found that strong self-efficacy beliefs in reading support the development of fluent reading skills, which is one of important components of the reading process. According to social cognitive theory, self-efficacy beliefs affect students' behavioral tendencies and choices (Bandura, 1995). This is also true for students' choices regarding reading texts. While students with low reading self-efficacy tend to avoid compelling texts, those with strong self-efficacy beliefs prefer challenging ones (Wigdield \& Guthrie, 1997). Thus, it can be argued that students who successfully read the texts they perceive as compelling will get stronger self-efficacy beliefs and they will continue to read compelling texts in the future. It can also be claimed that as they encounter different words and complex sentence structures in this process, their reading skills such as vocabulary and reading fluency improve more than their peers who prefer easy texts. In addition, the study also finds that self-efficacy has an indirect effect on reading success through the variable of reading enjoyment. In this respect, it can be said that strong self-efficacy beliefs about reading encourage students to read more by supporting their feelings about reading and thus contribute to their reading success.

The findings of the study suggest that students' perceptions of teachers' behaviours that encourage reading engagement predict their reading success. In addition, students' such perceptions indirectly affect their success through their level of reading enjoyment and reading self-efficacy. In other words, teachers' supportive behaviours such as encouraging students to share their views on the text, asking motivating questions for active participation into the lesson, and showing how to associate information in the text with their prior knowledge contribute to reading success as they enable them to enjoy reading more and develop strong self-efficacy beliefs. Students' reading enjoyment levels and reading selfefficacy beliefs are seen as components of reading motivation (Guthrie et al., 2007; Wigfileld, 1997). Students with high reading motivation tend to look for various reading materials that appeal to their interests and spend more time reading (Cox \& Guthrie, 2001; Wang \& Guthrie, 2004). They actively participate in the reading process, use reading strategies, try to associate the information in the text with their prior knowledge, and resist difficulties. Therefore, they are successful readers (Guthrie et al., 1999; Guthrie \& Wigfield, 2000). In this context, it can be argued that teachers' attitudes that encourage engagement increase students' motivation to read and support their success. There are similar studies demonstrating that teachers' supportive and positive behaviours have a positive effect on students' success and motivation levels (Ahmed, Minnaert, van der Werf \& Kuyper, 2010; Federici \& Skaalvik, 2014; Furrer \& Skinner, 2003). In this respect, it is suggested that Turkish teachers should do reading activities that ensure active participation of students so that they contribute to students' reading success. In addition, it is also believed that identifying students who do not like reading or have low self-efficacy beliefs in reading can be helpful to include them in intervention programs developed for this purpose.

The results of this study highlight the effects of teachers' behaviors encouraging reading engagement, reading enjoyment, and reading self-efficacy on reading success. However, the findings of the study have some limitations. Since PISA data are used in the study, the 
findings are limited to the data obtained from students aged 15 years. The model of the study can be retested in different samples in terms of age and class level. In addition, the model can be enriched by adding new mediator variables such as the total time spent for reading, the use of reading strategies and self-regulation.

\section{References}

Aarnoutse, C., \& van Leeuwe, J. (1998). Relation between reading comprehension, vocabulary, reading pleasure, and reading frequency. Educational Research and Evaluation, 4(2), 143-166.

Ahmed, W., Minnaert, A., van der Werf, G., \& Kuyper, H. (2010). Perceived social support and early adolescents' achievement: The mediational roles of motivational beliefs and emotions. Journal of Youth and Adolescence, 39(1), 36-46.

Ary, D., Jacobs, L. C., \& Sorensen, C. (2010). Introduction to research in education (8th ed.). Belmont: Cengage Learning.

Bandura, A. (1982). Self-efficacy mechanism in human agency. American Psychologist, $37(2), 122-147$.

Bandura, A. (1995). Exercise of personal and collective efficacy in changing societies. In A. Bandura (Ed.), Self-efficacy in changing societies (pp. 1-45). New York: Cambridge University Press.

Bandura, A. (2006). Guide for constructing self-efficacy scales. In F. Pajares \& T. Urdan (Eds.), Self-efficacy beliefs for adolescents (pp. 307-337). Greenwich: Information Age.

Barber, A. T., \& Klauda, S. L. (2020). How reading motivation and engagement enable reading achievement: Policy implications. Policy Insights from the Behavioral and Brain Sciences, 7(1), 27-34.

Baron, P., \& Corbin, L. (2012). Student engagement: Rhetoric and reality. Higher Education Research \& Development, 31(6), 759-772.

Bentler, P. M. (1990). Comparative fit indexes in structural models. Psychological Bulletin, 107(2), 238-46.

Byrne, B. (2010). Structural equation modeling with AMOS: Basic concepts, applications, and programming. New York: Routledge.

Cheema, J. R. (2018). Adolescents' enjoyment of reading as a predictor of reading achievement: New evidence from a cross-country survey. Journal of Research in Reading, 41,149-162.

Chen, F., Sakyi, A., \& Cui, Y. (2021). Linking student, home, and school factors to reading achievement: the mediating role of reading self-efficacy. Educational Psychology, 120.

Clark, C. \& De Zoysa, S. (2012). Mapping the interrelationships of reading enjoyment, attitudes, behaviour and attainment. Retrieved from: https://files.eric.ed.gov/fulltext/ED496343.pdf

Cox, K. E., \& Guthrie, J. T. (2001). Motivational and cognitive contributions to students' amount of reading. Contemporary Educational Psychology, 26(1), 116-131.

Cunningham, A. E., \& Stanovich, K. E. (1998). What reading does for the mind. American Educator, 22, 8-17.

Ertem, H. Y. (2020). Examination of Turkey's PISA 2018 reading literacy scores within student-level and school-level variables. Participatory Educational Research, 8(1), 248-264. 
Finn, J. D., \& Zimmer, K. S. (2012). Student engagement: What is it? Why does it matter? In S. L. Christenson, A. L. Reschly, \& C. Wylie (Eds.), Handbook of research on student engagement (pp. 97-133). New York: Springer.

Fraenkel, J. R., \& Wallen N. E. (2009). How to desing and evaluate research in education (7th ed.). New Yok: McGraw-Hill.

Fredricks, J. A., Blumenfeld, P. C., \& Paris, A. H. (2004). School engagement: Potential of the concept, state of the evidence. Review of Educational Research, 74(1), 59-109.

Furrer, C., \& Skinner, E. (2003). Sense of relatedness as a factor in children's academic engagement and performance. Journal of Educational Psychology, 95(1), 148-162.

Guthrie, J. T., Klauda, S. L., \& Ho, A. N. (2013). Modeling the relationships among reading instruction, motivation, engagement, and achievement for adolescents. Reading Research Quarterly, 48, 9-26.

Guthrie, J. T., McRae, A., \& Klauda, S. L. (2007). Contributions of concept-oriented reading instruction to knowledge about interventions for motivations in reading. Educational Psychologist, 42(4), 237-250.

Guthrie, J. T., \& Wigfield, A. (2005). Roles of motivation and engagement in reading comprehension assessment. In S. G. Paris \& S. A. Stahl (Eds.), Children's reading comprehension and assessment (pp. 187-213). New Jersey: Lawrence Erlbaum.

Hornstra, L., van der Veen, I., \& Peetsma, T. (2016). Domain-specificity of motivation: A longitudinal study in upper primary school. Learning and Individual Differences, 51, 167-178.

Inda-Caro, M., Maulana, R., Fernández-García, C. M., Peña-Calvo, J. V., del Carmen Rodríguez-Menéndez, M., \& Helms-Lorenz, M. (2019). Validating a model of effective teaching behaviour and student engagement: Perspectives from Spanish students. Learning Environments Research, 22(2), 229-251.

Jennifer, J. M., \& Ponniah, R. J. (2015). Pleasure reading cures readicide and facilitates academic reading. Journal on English Language Teaching, 5(4), 1-5.

Juel, C., \& Leavell, J. A. (1988). Retention and nonretention of at-risk readers in first grade and their subsequent reading achievement. Journal of Learning Disabilities, 21(9), 571-580.

Klassen, R. M. (2010). The confidence to manage learning: The self-efficacy for selfregulated learning of early adolescents with learning disabilities. Learning Disabilities Quarterly, 33, 19-30.

Klem, A. M., \& Connell, J. P. (2004). Relationships matter: Linking teacher support to student engagement and achievement. Journal of School Health, 74, 262-273.

Kuşdemir, Y., \& Bulut, P. (2018). The Relationship between Elementary School Students' Reading Comprehension and Reading Motivation. Journal of Education and Training Studies, 6(12), 97-110.

Linnenbrink, E. A., \& Pintrich, P. R. (2003). The role of self-efficacy beliefs instudent engagement and learning intheclassroom. Reading \& Writing Quarterly, 19(2), 119137.

Locher, F., \& Pfost, M. (2020). The relation between time spent reading and reading comprehension throughout the life course. Journal of Research in Reading, 43(1), 5777.

Maddux, J. E. (2002). Self-efficacy: The power of believing you can. In C. R. Sbyder \& S. J. Lopez (Eds.), Handbook of positive psychology (pp. 277-287). New York: Oxford University Press.

McGeown, S. P., Johnston, R. S., Walker, J., Howatson, K., Stockburn, A., \& Dufton, P. (2015). The relationship between young children's enjoyment of learning to read, reading attitudes, confidence and attainment. Educational Research, 57(4), 389-402. 
Mislevy, R. J. (1991). Randomization-based inference about latent variables from complex samples. Psychometrika, 56(2), 177-196.

Newman, F. M., Wehlage, G. G., \& Lamborn, S. D. (1992). The significance and sources of student engagement. In F. M. Newman (Ed.), Student engagement and achievement in American secondary schools (pp.11-40). New York: Teacher College Press.

Okkinga, M., van Steensel, R., van Gelderen, A. J., \& Sleegers, P. J. (2018). Effects of reciprocal teaching on reading comprehension of low-achieving adolescents. The importance of specific teacher skills. Journal of research in reading, 41(1), 20-41.

Özbay, M., Bağc1, H., \& Uyar, Y. (2008). Evaluation of the preservice Turkish teachers' attitudes towards reading habit according to some variables. Inonu University Journal of the Faculty of Education, 9(15), 117-136.

Pajares, F. (2006). Self-efficacy during childhood and adolescence: Implications for teachers and parents. In F. Pajares \& T. Urdan (Eds.), Self-efficacy beliefs of adolescencents (pp. 339-367). Greenwich: Information Age.

Parsons, J., \& Taylor, L. (2011). Improving student engagement. Current Issues in Education, 14(1), 1-32.

Pecjak, S., Podlesek, A., \& Pirc, T. (2011). Model of reading comprehension for 5th grade students. Studia Psychologica, 53(1), 53-67.

Peura, P., Aro, T., Viholainen, H., Räikkönen, E., Usher, E. L., Sorvo, R., \& Aro, M. (2019). Reading self-efficacy and reading fluency development among primary school children: Does specificity of self-efficacy matter?. Learning and Individual Differences, 73, 67-78.

Rogiers, A., Van Keer, H., \& Merchie, E. (2020). The profile of the skilled reader: An investigation into the role of reading enjoyment and student characteristics. International Journal of Educational Research, 99, 101512.

Sabol, T. J., \& Pianta, R. C. (2012). Recent trends in research on teacher-child relationships. Attachment \& Human Development, 14(3), 213-231.

Samuels, S. J. \& Kamil, M. L. (1998). Models of the reading process. In. P. L. Carrel, J. Devine \& D. E. Eskey (Eds.), Interactive approaches to second language reading (pp. 22-36). Cambridge: Cambridge University Press.

Schreiber, J. B., Nora, A., Stage, F. K., Barlow, E. A., \& King, J. (2006). Reporting structural equation modeling and confirmatory factor analysis results: A review. The Journal of Educational Research, 99(6), 323-338.

Schöber, C., Schütte, K., Köller, O., McElvany, N., \& Gebauer, M. M. (2018). Reciprocal effects between self-efficacy and achievement in mathematics and reading. Learning and Individual Differences, 63, 1-11.

Schunk, D. H., \& Rice, M. J. (1993). Strategy fading and progress feedback: Effects on selfefficacy and comprehension among students receiving remedial reading services. The Journal of Special Education, 27, 257-276.

Schunk, D.H. , \& Zimmerman, B.J. (1997). Developing self-efficacious readers and writers: The role of social and self-regulatory processes. In J. T. Guthrie \& A. Wigfield (Eds.), Reading engagement: Motivating readers through integrated instruction (pp. 34-50). Newark: International Reading Association.

Sherab, K. (2013). Strategies for encouraging behavioural and cognitive engagement of preservice student-teachers in Bhutan: An action research case study. Educational Action Research, 21(2), 164-184.

Slot, E., Akkerman, S., \& Wubbels, T. (2019). Adolescents' interest experience in daily life in and across family and peer contexts. European Journal of Psychology of Education, 34(1), 25-43. 
Sofyan, D., \& Jayanti, F. G. (2019). The correlation between reading self-efficacy and reading comprehension. Journal of English Education and Teaching, 3(1), 1-13.

Stutz, F., Schaffner, E., \& Schiefele, U. (2016). Relations among reading motivation, reading amount, and reading comprehension in the early elementary grades. Learning and Individual Differences, 45, 101-113.

Taboada, A., Townsend, D., \& Boynton, M. J. (2013). Mediating effects of reading engagement on the reading comprehension of early adolescent English language learners. Reading \& Writing Quarterly, 29(4), 309-332.

Tavşancıl, E., Yıldırım, O., \& Demir, S. B. (2019). Direct and indirect effects of learning strategies and reading enjoyment on PISA 2009 reading performance. Eurasian Journal of Educational Research, 19(82), 169-190.

Toste, J. R., Didion, L., Peng, P., Filderman, M. J., \& McClelland, A. M. (2020). A metaanalytic review of the relations between motivation and reading achievement for $\mathrm{K}-12$ students. Review of Educational Research, 90(3), 420-456.

Wang, J. H. Y., \& Guthrie, J. T. (2004). Modeling the effects of intrinsic motivation, extrinsic motivation, amount of reading, and past reading achievement on text comprehension between US and Chinese students. Reading Research Quarterly, 39(2), 162-186.

Wigfield, A. (1997). Reading motivation: A domain-specific approach to motivation. Educational Psychologist, 32(2), 59-68.

Wigfield, A., \& Guthrie, J. T. (1997). Relations of children's motivation for reading to the amount and breadth or their reading. Journal of Educational Psychology, 89(3), 420432.

Wilkinson, K., Andries, V., Howarth, D., Bonsall, J., Sabeti, S., \& McGeown, S. (2020). Reading during adolescence: Why adolescents choose (or do not choose) books. Journal of Adolescent \& Adult Literacy, 64(2), 157-166.

Zaccoletti, S., Altoè, G., \& Mason, L. (2020). Enjoyment, anxiety and boredom, and their control-value antecedents as predictors of reading comprehension. Learning and Individual Differences, 79, 1-11.

Zepke, N., \& Leach, L. (2010). Improving student engagement: Ten proposals for action. Active Learning in Higher Education, 11(3), 167-177.

Zhao, W., Song, Y., Zhao, Q., \& Zhang, R. (2019). The effect of teacher support on primary school students' reading engagement: the mediating role of reading interest and chinese academic self-concept. Educational Psychology, 39(2), 236-253. 